\title{
The Microfilming Functions Used by the Secretaries in Managing Office Records in Government Establishments in Anambra State, Nigeria
}

\author{
Oguejiofor Chinwe Sussan ${ }^{1}$, Ile Chika Madu \\ ${ }^{1}$ Department of Business Education, Madonna University, Livonia, USA \\ ${ }^{2}$ Department of Vocational Education, Nnamdi Azikiwe University, Awka, Nigeria
}

Email address:

ilechika2011@yahoo.com (I. C. Madu)

To cite this article:

Oguejiofor Chinwe Sussan, Ile Chika Madu. The Microfilming Functions Used by the Secretaries in Managing Office Records in Government Establishments in Anambra State, Nigeria. Education Journal. Special Issue: New Dimensions in Vocational Business Education Teaching and Learning. Vol. 4, No. 6-1, 2015, pp. 15-18. doi: 10.11648/j.edu.s.2015040601.13

\begin{abstract}
This study determined the microfilming functions used by the secretaries in managing office records in government establishments in Anambra State, Nigeria.The population was 298 secretaries.Structured questionnaire was used.The instrument was validated by three experts.Its internal consistency was determined using Cronbach Alpha and the result was high reliability coefficient of 0.61.Data collected were analysed using mean and standard deviation, while t-test was used to test the null hypothesis. The findings showed that secretaries used most of the micro-filming functions identified by this study.Based on the findings, it was recommended amongst others that the training institutions should ensure that they instruct trainee secretaries on the skills needed to manage records effectively and efficiently in offices. Such skills should also be incorporated into the office technology and management curriculum.
\end{abstract}

Keywords: Microfilming, Functions, Secretaries, Office Records

\section{Introduction}

Innovations in office technology has resulted in a drastic change in the nature, composition and role of the office. The various professional services offered in offices are seriously adjusting to the ethics and modes of operation that can stand the test of time. Nwosu (1998) suggested that secretaries today require new sets of skills in the application of office functions for information processing, management, employment, office productivity, job retention, job success and job satisfaction.

According to him, secretaries who are not well equipped with these new skills and competencies, knowledge and abilities will soon render themselves obsolete, redundant or even thrown out of jobs. There is no doubt that the sterotype picture of a secretary of the past, completely with traditional office competencies is beginning to fade and the image of the new secretary with electronic competencies is emerging. Organisations need secretaries who can plan, coordinate, control and implement organisational activities and this cannot be possible without effective record management practices. There is therefore, the need to identify the micromfilming functions used by secretaries in managing office records.

According to Oliverio and Pasework (1973), microfilming refers to the process of photographically reducing documents to a fraction of their original size to fit on films. Chopra and Chopra (2006) described microfilming as the photographic process of retaining information given in office documents and records. The record is first photographed on film at reduced size, then the film is developed to serve as permanent record. Under this system, films are prepared from the original document and then placed in file cabinets specially built for microfilms. When the record is again required, the film clerk or secretary locates the subject on the film, places the film on the projector reader and locates the references. The film can also be enlarged to a large size.

Kanzi (2010), defined record as the information captured for re-use at a later date as evidence of an activity or action undertaken and a basis on which future decisions are made. Cow (2001) also posited that a record is a specific piece of recorded information generated, collected or received in the institution in the conduct or completion of an activity, and 
that which composes sufficient content, context and structure to provide proof of evidence of activity.

Records should be kept for the purposes of documenting evidence of every significant activity undertaken in an organization to ensure a smooth connection between the past, present and future operations of the system.According to Oliverio and Pasework (1973), the steps involved in micrographic process include:

a. Gathering records so they can be recorded on microfilm.

b. Using a micrographic camera to take picture of the hard copies.

c. Developing the microfilm.

d. Using a device called "a reader" to read the micro-image

Developments in electronic data storage have revolutionized the speed of retrieval of information; allowed greater and easier access to vast quantities of records without the need to store papers in bulky filing cabinets.Chukwumezie (2005), therefore advised secretaries to recognize and appreciate the potentials of these electronic filing methods, since the filing of information held in paper disk or films are important functions of secretaries in automated offices.It is in view of this that this paper sought to determine the microfilming functions used by secretaries in managing office records in government establishments in Anambra State, Nigeria.

The purpose of the study therefore, was to determine the microfilming functions used by secretaries in managing office records in government establishments in Anambra State, Nigeria.

\section{Research Questions}

The study was guided by one research question: What are the microfilming functions used by secretaries in managing records in government establishments in Anambra State, Nigeria?

\subsection{Hypothesis}

The following null hypothesis was tested at 0.05 level of significance: There is no significance difference in the mean ratings of experience and less experience secretaries on the microfilming functions used by secretaries in managing office records in government establishments in Anambra State Nigeria.

\subsection{Method}

This study adopted a descriptive survey design. This design was considered most appropriate for the study because survey studies utilize questionnaire as a tool in obtaining information. The secretaries in Anambra State civil service formed the population of this study. Respondents were asked to rate each of the items on a four point scale as follows. Often used (4) sometimes used (3) rarely used (2) never used (1). The instrument for data collection was validated through expert judgement. The reliability of the instrument was established using the
Cronbach alpha. The instrument yielded approximated reliability indices of 0.61 . The boundary limit of 2.50 was used to determine the acceptability of questionnaire items. Any function with a mean score of 2.50 and above was considered used and a function with a mean score below 2.50 was considered not used by the secretaries.

The researchers administered the questionnaire with the help of two research assistants who returned same within two weeks of administration. The entire copies of the questionnaire were returned and used for analysis. The hypothesis was tested at 0.05 level of significance.

\section{Results}

What are the microfilming functions used by secretaries in managing records $>$

Table 1. Mean Ratings on the microfilming functions used by secretaries in managing office records.

\begin{tabular}{|c|c|c|c|c|}
\hline $\mathbf{S} / \mathbf{N}$ & ITEMS & $\mathbf{X}$ & SD & DECISION \\
\hline 1 & $\begin{array}{l}\text { Photographs document on } \\
\text { film }\end{array}$ & 2.33 & 1.26 & Not used \\
\hline 2 & $\begin{array}{l}\text { Developing documents to } \\
\text { serve as permanent records }\end{array}$ & 2.84 & .98 & Used \\
\hline 3 & Locating subjects on a film & 2.25 & 1.09 & Not used \\
\hline 4. & $\begin{array}{l}\text { Reducing exact images in } \\
\text { documents }\end{array}$ & 1.75 & 1.02 & Not used \\
\hline 5. & Using graphic images & 1.83 & 1.15 & Not used \\
\hline 6. & $\begin{array}{l}\text { Passwording stored } \\
\text { document to protect data } \\
\text { from unauthorized access }\end{array}$ & 2.84 & 1.06 & Used \\
\hline 7. & Ensuring file integrity & 3.43 & .76 & Used \\
\hline 8. & $\begin{array}{l}\text { Ensuring security of } \\
\text { documents }\end{array}$ & 3.43 & .76 & Used \\
\hline 9. & $\begin{array}{l}\text { Separate transaction } \\
\text { documents }\end{array}$ & 3.26 & 1.02 & Used \\
\hline 10. & $\begin{array}{l}\text { Knowledge to apply } \\
\text { electronic referencing }\end{array}$ & 3.17 & .98 & Used \\
\hline 11. & $\begin{array}{l}\text { Scanning and } \\
\text { digitizingmicrofilmed images }\end{array}$ & 2.40 & 1.33 & Not used \\
\hline 12. & $\begin{array}{l}\text { Displaying micro images on a } \\
\text { screen }\end{array}$ & 2.57 & 1.19 & Used \\
\hline 13. & $\begin{array}{l}\text { Enlarging the document to a } \\
\text { readable size }\end{array}$ & 2.83 & 1.29 & Used \\
\hline 14. & $\begin{array}{l}\text { using microscopic lens to } \\
\text { read documents }\end{array}$ & 2.33 & 1.10 & Not used \\
\hline
\end{tabular}

The result in Table 1 shows that items 2, 6, 7, 8, 9, 10, 12 and 31 were the microfilming functions used by the secretaries.However, items 1, 3, 4, 5, 11 and 14 were not used by the secretaries. This implies that the respondents used microfilming functions in developing documents to serve as permanent records, passwording stored document to protect data from unauthorized access, ensuring file integrity, ensuring security of documents, separating transaction documents application of electronic referencing, display of micro images on a screen and enlarging the document to a readable size. However, the secretaries were seen not to use functions in photographing document on film, locating the subject on a film, reducing exact images, using graphic images and using microscopic lens. 
Table 2. T-test results of difference between the mean responses of experienced and less experienced secretaries on the microfilming functions used by secretaries in offices of government establishments in Anambra State, Nigeria.

\begin{tabular}{|c|c|c|c|c|c|c|c|c|}
\hline Item & Category & $\mathbf{X}$ & SD & $\mathbf{N}$ & t.cal & Alpha & t.crit & decision \\
\hline \multirow{2}{*}{1} & Less experience & 2.83 & 1.34 & 150 & \multirow{2}{*}{7.67} & \multirow{2}{*}{0.05} & \multirow{2}{*}{1.96} & \multirow{2}{*}{ Reject } \\
\hline & Experience & 1.81 & .89 & 148 & & & & \\
\hline \multirow{2}{*}{2} & Less experience & 3.16 & 1.07 & 150 & 6.18 & \multirow{2}{*}{0.05} & \multirow{2}{*}{1.96} & \multirow{2}{*}{ Reject } \\
\hline & Experience & 2.50 & .76 & 148 & & & & \\
\hline \multirow[b]{2}{*}{3} & Less experience & 2.16 & 1.34 & 150 & 1.30 & \multirow{2}{*}{0.05} & \multirow{2}{*}{1.96} & \multirow{2}{*}{ Reject } \\
\hline & Experience & 2.33 & .75 & 148 & & & & \\
\hline 4 & Less experience & 1.83 & 1.21 & 150 & 1.46 & 0.05 & 1.96 & Reject \\
\hline \multirow{2}{*}{5} & Less experience & 2.00 & 1.41 & 150 & 2.57 & \multirow{2}{*}{0.05} & \multirow{2}{*}{1.96} & \multirow{2}{*}{ Reject } \\
\hline & Experience & 1.66 & .752 & 148 & & & & \\
\hline \multirow{2}{*}{6} & Less experience & 2.83 & 1.34 & 150 & .02 & \multirow{2}{*}{0.05} & \multirow{2}{*}{1.96} & \multirow{2}{*}{ Accept } \\
\hline & Experience & 2.83 & .648 & 148 & & & & \\
\hline \multirow{2}{*}{7} & Less experience & 3.50 & .766 & 150 & \multirow{2}{*}{1.78} & \multirow{2}{*}{0.05} & \multirow{2}{*}{1.96} & \multirow{2}{*}{ Accept } \\
\hline & Experience & 3.34 & .744 & 148 & & & & \\
\hline 8 & Less experience & 3.66 & .748 & 150 & 500 & 005 & 106 & Doinct \\
\hline 9 & Less experience & 4.00 & .00 & 150 & 1890 & 005 & 196 & Reiect \\
\hline & Experience & 2.50 & .965 & 148 & 18.90 & 0.05 & 1.90 & Keject \\
\hline 10 & Less experience & 3.33 & 1.10 & 150 & 206 & 005 & 106 & Paingt \\
\hline 10 & Experience & 3.00 & .81 & 148 & 2.90 & 0.05 & 1.90 & Keject \\
\hline 11 & Less experience & 2.50 & 1.50 & 150 & 119 & 005 & 196 & Accent \\
\hline 11 & Experience & 2.31 & 1.10 & 148 & & & 1.90 & \\
\hline 12 & Less experience & 2.66 & 1.10 & 150 & 131 & 005 & 106 & Acrent \\
\hline 12 & Experience & 2.48 & 1.26 & 148 & 1.31 & 0.05 & 1.90 & Асcерt \\
\hline 13 & Less experience & 3.50 & 1.12 & 150 & & & & \\
\hline 13 & Experience & 2.14 & 1.06 & 148 & 10.67 & 0.05 & 1.96 & Reject \\
\hline 14 & Less experience & 2.50 & 1.12 & 150 & 272 & 005 & 106 & Paiso \\
\hline 14 & Experience & 2.15 & 1.06 & 148 & 2.12 & 0.05 & 1.90 & Keject \\
\hline
\end{tabular}

The results of t-test analysis in Table 2 showed that items $1,2,5,8,9,10,13$ and 14 obtained calculated t-values that are greater than the critical $t$-value at 0.05 . The null hypothesis was therefore rejected.However, items 3,4,6,7,11 and 12 obtained critical t-values that are greater than the calculated t-values, the null hypothesis was therefore accepted.

\section{Discussion}

The findings of the study revealed that some microfilming functions were used by the secretaries while some of the functions were not used.It could be concluded that secretaries studied used microfilming functions because 8 out of the 14 items statements obtained mean scores greater than 2.50 which represented the criterion mean set for the study. That the secretaries do not use all the microfilming functions studied was not surprising.This is because Nigerian offices according to Nwosu (2002), are still transforming from traditional to electronic.They are not yet fully electronic and not purely traditional.

Results of the t-test analysis of the responses of secretaries showed that there was a significant difference in the mean responses of less experienced and experienced secretaries studied.This result is expected, since experience can only be bought with age and extended stay on the job practice.Experience is a veritable index in the acquisition of skills required in a given vocation. This is in agreement with the view of Maduabuchi (2012) who reported that physical characteristics of experience seem to be relatively important in terms of ultimate office records management competencies.

\section{Conclusion}

From the findings of the study, it is clear that secretaries were found not to use some of the microfilming functions studied.Education the world all over is being designed to fit more into the electronic age for the purpose of efficiency.Secretaries ought to keep abreast with these changes or be rendered obsolete.Organizations can therefore only employ those secretaries who possess the basic microfilming skills to manage records effectively and efficiently in offices.

\section{Recommendations}

Based on the findings of the study, it is hereby recommended that:

1. The training institutions should ensure that they instruct trainee secretaries on the skills needed to manage electronic records effectively and efficiently in offices. This should also be incorporated into the office technology and management curriculum.

2. There is need for various forms of in-service trainings in the area of electronic records management in offices to 
equip secretaries with the skills needed to manage records.

3. Government should recognize the need for proper electronic records management skills and its benefits to the progress of any organization. Consequently, government has to provide considerable national resources both financially and otherwise to equip offices with these machines and equipment.

\section{References}

[1] Chopra, R.K, and Chopra, A. (2006). Office management. New Delhi: Heimalaye Publishing House.

[2] Chukwumezie, F.U. (2005). Appraisal of information and communication technology competences required of senior secondary school business education graduates. Business Education Journal, V(1), 122-136.

[3] Cox, R.J. (2001). Managing records as evidence information. London: Westport.

[4] Healey, R.G. (2015). Database management systems (online: http://www.colardo.edu/geography/classhomepages/geo.../ Healey 91.pdf)
[5] Kanzi, N. (2010). An investigation of the role of records management with specific reference to Amathole District Municipality. Unpublished MPA theses, Nelson Mandela Metropolitan University: Port Elizabeth.

[6] Mmaduabuchi (2012).Employers' Assessment of information and communication technology competencies possessed by secretaries in Business Organizations in Onitsha Council Areas. An unpublished M.Sc thesis. Submitted to the Department of Vocational Education, Nnamdi Azikiwe University, Awka.

[7] Nwosu, B.O (1998).The changing secretarial role for sustainable development in Nigeria: implications for office education. Journal of Business and Office Education, 1 (1), 19-24.

[8] Oliverio, E., James, R. B., Meeham, W., Pasework, R. and Mary, E. (1973). Clerical office practice, procedures. England: South-West Publishing Co.

[9] Rundell, M. (2007). Mcmillian English dictionary for advanced leaners. oxford: Mcmillian Education.

[10] Sawyer, S.C. \& William B.K (2001). Using information technology: A practical introduction to computers and communication. London: Irwin McGraw-Hill. 